\title{
DOSSIÊ AMÉRICA-LUSA
}

Larissa Urquiza Perez de Morais

É com grande prazer que a Revista Vernáculo apresenta neste volume o Dossiê América Lusa. Os trabalhos aqui reunidos mobilizaram diferentes conjuntos de fontes para um fim semelhante: um melhor entendimento do que foi a vida, e a morte, nos territórios americanos controlados por Portugal. Foram estudados documentos produzidos durante o período colonial, de tipo administrativo, assim como listas nominativas e livros paroquiais para desenvolver os estudos realizados, que nos mostram diversas faces da sociedade do antigo regime contemplando as questões de relações sociais, identitárias, dentro da esfera civil e religiosa.

Rachel Marques discute em seu artigo "a designação social por faixa etária atribuída a jovens escravos nos registros de óbito" da região do que atualmente é a cidade de Pelotas - RS do início do século XIX. A autora procura trabalhar como os termos usados nas designações sociais nos levam a compreender a indefinição social desses escravos.

Frencielle de Souza pretende estudar as relações sociais do período colonial brasileiro envolvendo os índios Guaranis na região de 
Revista Vernáculo, $n^{\circ} 29,1^{\circ}$ sem/2012

Rio Grande de São Pedro, onde atualmente é a cidade de Rio Grande RS. De Souza trabalha as questões da hierarquia católica nos rituais fúnebres, utilizando também registros de óbito, onde trabalha a questão de como esfera religiosa e civil estão interligadas e interferindo uma na outra.

Alysson Costa, utilizando os registros de batismo da região do Rio Pardo do século XVIII, trata em seu artigo da questão de identidade indígena da população dos Sete Povos das Missões. Já Jonas Pegoraro procura inserir a Comarca de Paranaguá dentro a dinâmica que foi o Império Ultramarino português também no período colonial.

O resumo de monografia integrante desde dossiê também utilizará como fonte os registros de batismo, que segundo a autora "nos permite conhecer as sociedades do antigo regime". Alexandra Alvim tratará da "inserção social de imigrantes açorianos na povoação de Santo Amaro - RS; será estudado o papel da Igreja católica levando em conta a utilização do compadrio na hora do batismo no período de 1757-1774. A autora utilizou três livros de registros paroquiais de batismo da freguesia de Bom Jesus do Triunfo; um livro destinado para a população branca; um segundo, para a população escrava; e um terceiro, para a população de ilhéus. 